DOI: $10.20287 /$ doc.d24.ac04

\title{
Shoah de Claude Lanzmann: entre a memória da dor e a radicalidade da morte nos campos nazistas
}

\author{
Ricardo Lessa Filho*
}

In memoriam de Claude Lanzmann

Shoah (França, 1985, $566 \mathrm{~min}$ )

Direção: Claude Lanzmann

Roteiro: Claude Lanzmann

Produção: Séverine Olivier-Lacamp e Stella Quef

Som: Bernard Aubouy, Danielle Fillios, Anne-Marie Lhote e Michel Vionnet

Direção de Fotografia: Dominique Chapuis, Jimmy Glasberg, Phil Gries e

William Lubtchansky

Edição: Ziva Postec e Anna Ruiz

Os mortos demandam os vivos: recordem-se de tudo e contem-no; não somente para combater os campos, mas sim para que nossa vida, ao deixar de si uma marca, conserve seu sentido.

Tzvetan Todorov

\section{Introdução}

Um campo de extermínio ainda está habitado pelos seus mortos. E somente um sobrevivente pode regressar a um campo, porque ninguém "regressa" onde nunca esteve. Para isolar a esperança de que não se repita, o horror deve ser experimentado; para que o corpo aprenda a reconhecer sua pestilência e para afastar-se dela, com sua sabedoria soterrada de animal. Para experimentar o horror, é necessário libertar o umbral do "inimaginável" e ser casca, pele imediata da árvore exposta sem remédio ao dano. Arranhar a dor do outro que já não pode ser tocada; dissolver a linha do tempo para acompanha-lo em seu martírio; deambular para encontrar o outro (o perdido, o queimado, o desaparecido) nas flores que germinam na terra arrasada, alimentando-se de ossos e cinzas.

* MDoutorando. Universidade Federal de Pernambuco - UFPE, Centro de Artes e Comunicação, Programa de Pós-Graduação em Comunicação. 50670-901, Recife, Brasil. E-mail: ricardolessafilho@ hotmail.com 
Assim, no exato contraponto ao filme mais famoso sobre o horror nazista, Noite e neblina (1955) de Alain Resnais, existe Claude Lanzmann e o seu filme Shoah ${ }^{1}$ (1985). Um contraponto que irrompe aos olhos logo diante da metragem de ambos os filmes: enquanto o filme de Resnais tem aproximadamente trinta minutos, o filme de Lanzmann possui uma colossal duração de mais de nove horas. Mas mais do que a brutal diferença de metragem, a cisão entre as estéticas destes filmes os fazem documentos imprescindíveis da barbárie nazista no momento em que um se instala no polo absolutamente contrário do outro. A saber: Noite e neblina parte da imagem-arquivo para tentar restaurar as ruínas da catástrofe, revela-nos a partir do arquivo imagético sobrevivente um traço do extermínio que o regime nazista instaurou no mundo. Este traço da memória genocidária ao mesmo tempo tão frágil e tão potencializado por um horror que nos fere a cada retorno possível, este momento tão difícil de suportar que é olhar e sentir aquelas imagens de seres humanos desorbitados pelo próprio homem, figuras que nos sequestram, que nos raptam ao ponto de pensar que o Lager $^{2}$ foi de fato um outro mundo. Assim é a força do arquivo em Noite e neblina.

Shoah, por sua vez, vai ao fundo do abismo da palavra e da memória desta palavra. O tempo é presentificado nos rostos das testemunhas, a memória reage enquanto processo de afundamento: é o rasgar da ferida, do trauma da catástrofe, onde o único retorno possível se dá ou no silêncio (na recusa em contar, em lembrar) ou a partir das lágrimas dos sobreviventes, que quando retornam da entrada do abismo da memória, voltam exauridos, extenuados, e seus rostos revelam marcas outrora imperceptíveis - vestígios de desespero, de polegadas de um horror trespassado e insustentável à própria memória. Supostamente não existe imagem-arquivo. O arquivo no filme de Lanzmann está proibido de sussurrar sua história, sua dor. Shoah é assim o Bilderverbot (proibição das imagens) de Claude Lanzmann. E tentaremos desse modo analisar não somente a grandeza deste filme e de sua aura (testemunho fundamental do horror concentracionário) como também os equívocos filosóficos que a obra a posteriori acabou cristalizando à representação e à análise das imagens dos campos nazistas, de outro modo, tentaremos mostrar o profundo equívoco pelo desprezo ao arquivo e como o fim cíclico de toda imagem (por mais eterna que ela seja) é tornar-se excerto da história, arquivo daquilo que ela testemunha.

1. Basicamente o filme Shoah é composto por uma série de entrevistas sobre as experiências nos campos de extermínio poloneses, com três tipos de testemunhas da morte: vítimas da Solução Final (Endlösung), testemunhas presenciais e funcionários administrativos dos campos e da empresa ferroviária do Terceiro Reich.

2. Termo em alemão que significa "armazém". É assim que, também, os estudiosos da Shoah denominam os campos nazistas. 


\section{A memória da dor}

Há um fantasma que navega nas imagens iniciais de Shoah, uma cratera de sentindo, que mesmo olhando aquela terra tão verde e viva (o locus amoenus), as águas do rio Ner resplandecendo à presença do homem, há algo ainda assim que não parece fechar, complementar a sua história mesma. Há uma camuflagem ao horror do tempo genocidário. Uma sensação de peso insuportável parece residir entre as águas, as árvores, a terra, e, sobretudo, na face de $\mathrm{Si}$ mon Srebnik (fig.1). O filme nos mostra a topografia do campo de extermínio de Chelmno ${ }^{3}$ quase quatro décadas após o seu fim, e Srebnik é então introduzido à narrativa, e tal como a paisagem da Chelmno que ele retorna, existe uma marca em seu rosto, uma marca ao mesmo tempo tão abismal nos olhos (nestas pálpebras e globos que viram o homem ser exterminado da forma mais brutal pelo próprio homem; nesta resistência da vida que parece não suportar mais, justamente, o peso da lembrança) que emana uma ruptura de sentido quando tentamos desvendar o segredo que existe no seu local mais profundo, em seu abismo mais íntimo.

É neste espectro do inexplicável que Sánchez-Biosca relata os primeiros minutos de Shoah, não esquecendo de apontar aquilo que também percebemos, seja a presença e o peso do fantasma da morte, o estranho locus amoenus que parece perpetuar uma aporia ao logos; é no pélago de uma rememoração tão particular que a imagem encenada por Lanzmann acaba por afetar todo o cadre do real (o rosto de Srebnik) ${ }^{4}$ e do simbólico (o imaginar das chamas dos crematórios como um momento alucinatório):

Nada explica a estrutura (do filme) como o começo e o final. Shoah se abre sobre um espaço idílico, um locus amoenus atravessado por um rio. É Chelmno. Sobre uma barca, um homem envelhecido, entona uma canção. Segundo ato, acompanhado por uma câmera que escruta seu rosto, contempla um pequeno bosque: "É difícil de reconhecer - diz -, mas aqui queimaram pessoas". De repente, um fantasma impregna este espaço puro e límpido. O que na falta terrível - a sua nomeação por meio de imagens de arquivo (elas não existem aqui), o filme nos permite ver através de um encontro paralisador entre o testemunho e o lugar camuflado. Uma assustadora panorâmica desentranhada entre o belo campo polaco e a alucinação de uma imensa coluna de fogo, dos caminhões de gaseamento, sem que nada tenha sido mostrado. Lanzmann realiza uma encenação (em seu sentido dramatúrgico) empenhada em minar o pacífico presente para que emerja nesse momento incrível o que a "solução

3. Como nos lembra Lanzmann (1987: 17), das quatrocentas mil pessoas que chegaram a Chelmno, contabilizaram-se somente dois sobreviventes: o próprio Srebnik e Mordechai Podchlebnik.

4. Uma das grandes lições de Georges Bataille (1973) consiste que o real, por ser "impossível", não existe senão manifestando-se sob a forma de fragmentos, resquícios, objetos e vestígios. Ora, não é justamente por estilhaços que a presença de Srebnik nos é revelada? 
final” colocou em marcha; essa enigmática primeira vez que a engrenagem desencadeou. (Sánchez-Biosca, 2009: 130).

Lanzmann documenta acertadamente a "história pessoal" de Srebnik, já que ele

era então uma criança de treze anos e meio. Seu pai fora abatido sob seus olhos, no gueto de Lodz, sua mãe asfixiada nos caminhões de Chelmno. Os SS o alistaram em um dos comandos de "judeus de trabalho", que asseguravam a manutenção dos campos de extermínio e estavam eles próprios destinados à morte. Os tornozelos atados, como todos os seus companheiros, o menino atravessava todos os dias a aldeia de Chelmno. Deveu o fato de ser poupado, por mais tempo que os outros, à sua extrema agilidade, que o fazia ganhar as competições que os nazistas organizavam entre aqueles acorrentados, concursos de saltos ou de velocidade. E também à sua voz melodiosa: várias vezes por semana, quando era preciso alimentar os coelhos da coelheira SS, Simon Srebnik, vigiado por um guarda, subia o Ner em uma embarcação de fundo chato, até os confins da aldeia, na direção dos prados de alfafa. (Lanzmann, 1987: 18).

\section{E conclui:}

Na noite de 18 de janeiro de 1945, dois dias antes da chegada das tropas soviéticas, os nazistas mataram com uma bala na nuca os últimos "judeus de trabalho". Simon Srebnik foi executado também. A bala não atingiu os centros vitais. Voltando a si, rastejou até um chiqueiro de porcos. Um camponês polonês o recolheu. Um médico-major do Exército Vermelho cuidou dele, salvou-o. Alguns meses mais tarde, Simon partiu para Tel-Aviv com outros sobreviventes. Foi em Israel que eu o descobri. Convenci o menino cantor a voltar comigo a Chelmno. Ele tinha 47 anos. (Lanzmann, 1987: 19).

Com esse relato sintético, preciso e terrível da história de Srebnik, é possível começar a compreender o abismo de seus olhos, as marcas traçadas na pele do rosto: seus gestos parecem carregar os escombros do genocídio nazista; há um espectro enlutado em sua presença, que não só define sua alma em decalagem ao corpo, mas faz emergir uma dúvida sobre a própria vida, ou melhor, sobre a impossibilidade, de fato, de viver novamente, sobretudo quando a própria morte já o tinha rodeado duplamente: em Chelmno (na iminência do extermínio), e também com o tiro na nuca desferido pelo soldado nazista. A vida, mesmo ele tendo sobrevivido a tudo isso, parece uma esperança longínqua, quase impossível de ser tocada outra vez. Essa impossibilidade, aliás, radiografada em um determinado momento de Shoah, quando Srebnik, a pedido de Lanzmann, vai até uma sinagoga na região de Chelmno (fig.2): a lacuna fisionômica de Simon, um rosto incapaz de brilhar de novo, em contraste com os camponeses daquela região, que ao se depararem com a câmera de Lanzmann ficam alvoraçados, sorridentes, tagarelam, querem todos de algum modo falar, aparecer. 
Mas Srebnik parece guardar em seu próprio abismo as lágrimas congeladas do horror concentracionário, e o único gesto possível por ele concedido é um sorriso lânguido (e isso ocorre o tempo todo; é aquilo que marca a sua presença, o seu sempiterno luto), este exato momento onde a decalagem da sua presença lúgubre acaba por absorver toda a vida ao seu redor, e ao perceber isto, Lanzmann, lentamente, acaba por ir enquadrando cada vez mais próximo o rosto de Simon Srebnik, como se o espaço (e o tempo) também se encontrasse no entredito, fraturado pelo gesto de aproximação corporal até Srebnik que, agora, faz com que a pele do seu rosto ocupe todo o campo de nossa visão, legitimando desta maneira a aporia da sua vida. ${ }^{5}$

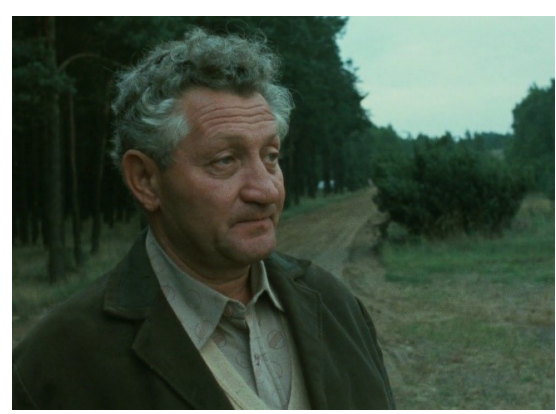

Figura 1. Srebnik, sozinho.

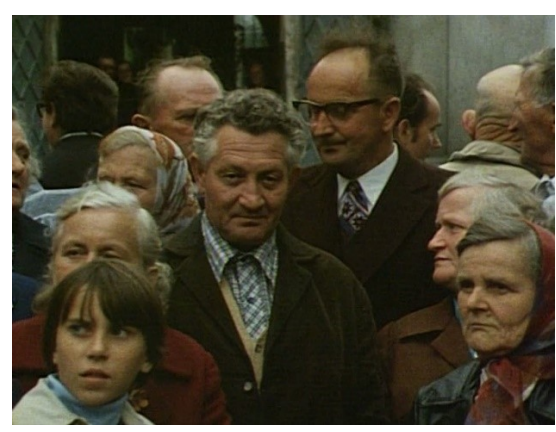

Figura 2 . Ele, rodeado.

5. Como diz o outro sobrevivente de Chelmno, Mordechai Podchlebnik, ao ser perguntado por Lanzmann sobre "o que está morto" em Srebnik, ele responde: “Tudo está morto. Tudo está morto, mas não se é senão um homem, e se quer viver. Então, é preciso esquecer. Ele agradece a Deus pelo que restou e pelo esquecimento" (Lanzmann, 1987: 22). 
A voz angelical de Srebnik o salvou do extermínio, mas não da morte. E sua vida já não mais poderia ser salva pelo cinema ${ }^{6}$. Seria Srebnik um "muçulmano" 7 ? Talvez. Mas a sua imagem é em si mesma um testemunho. É a sua presença no filme que possibilita a partir do ato da palavra (e de sua memória), uma representação possível da catástrofe nazista. A sensação que sentimos ecoar em mais de nove horas em Shoah é de imagens que aprofundam nosso resistir diante deste horror e ainda além, sustenta-nos e desafia-nos para uma representação possível dessa entidade destruidora, desse Behemoth real ${ }^{8}$. Afinal, "o que os SS quiseram destruir em Auschwitz não era apenas a vida, mas também [...] a própria forma do humano e, com ela, a sua imagem"(DidiHuberman, 2012: 64). Shoah faz com que exatamente a Shoah ${ }^{9}$ seja possível de ser representada, de outro modo, o filme nos possibilita imaginar as imagens - a partir da presença e dos testemunhos dos sobreviventes - deste momento genocidário que invadiu o mundo, e arranca do âmago do irrepresentável a ideia absoluta de algo que não pode, justamente, ter uma representação possível.

É justamente por sempre haver algo para ver e imaginar, que a representação de Auschwitz, na contramão daquilo teorizado por Lanzmann ${ }^{10}$, irrompe nas imagens de Shoah, a saber: por entre as vozes cortadas, por entre o choro e o silêncio que solapam a própria eficácia do dizer das testemunhas, existe a fissura onde a representação e a imaginação sempre poderão arrancar alguma coisa nova, alguma coisa onde o vestígio da história permanecerá apesar de tudo, obrigando-nos a repensar a imagem e todo o seu gesto político. O Nachleben ${ }^{11}$ da testemunha da Shoah, sua sobrevivência mesma está então submergida na profundeza da dor e da vergonha - em seus instantes de verdade:

havia algo para ver, de várias formas. Havia algo para ver, para ouvir, para sentir, para deduzir daquilo que víamos ou daquilo que não víamos (os comboios que ininterruptamente chegavam cheios e voltavam a partir vazios). [...] Víamos apesar de toda a censura, indubitáveis segmentos da "Solução final"mas não queríamos saber. Tal como a radicalidade do crime nazi nos obriga a repensar o direito e antropologia (como o mostrou Hannah Arendt); 141).

6. “os corpos não serão salvos pelo cinema. Os corpos já foram afundados” (Cangi, 2003:

7. No sentido de Primo Levi e teorizado por Giorgio Agamben (2008), do homem que, mesmo com vida, carrega consigo a aura da morte.

8. Desde muito cedo, o nazismo se comparou com este monstro bíblico, simétrico ao Leviatã. Ver Franz Neumann. Behemot. The structure and practice of National Socialism (2009).

9. Shoah em hebraico significa "destruição". Quando usarmos a palavra em referência ao filme de Lanzmann, ela aparecerá em itálico. Quando for referência à catástrofe nazista, a palavra aparecerá sem a marcação itálica.

10. Para o cineasta francês, a Shoah é irrepresentável e inimaginável, ao mesmo tempo que o seu filme é a obra absoluta e definitiva do genocídio nazista.

11. Termo em alemão que significa "sobrevivência". 
tal como a enormidade desta história nos obriga a repensar a narrativa, a memória e a escrita em geral (como o mostraram, cada um de sua forma, Primo Levi ou Paul Celan); também o 'inimaginável' de Auschwitz nos obriga, não a eliminar, mas antes a repensar a imagem, de cada vez que uma imagem de Auschwitz, ainda que lacunar, surge de repente, concretamente sob os nossos olhos. (Didi-Huberman, 2012: 85).

Gertrud Koch, como apontado por LaCapra (2009: 117), diz que a obra de Lanzmann trata-se de "uma transformação estética da experiência do extermínio", e conclui que "não se pode negar que o filme oferece, ademais, suficiente material e contribui com os necessários debates históricos e políticos". E que, claramente, esses necessários debates históricos e políticos são também representações outras e possíveis do genocídio nazista. Shoah, em sua presença colossal, assinala aquilo que Vidal-Naquet fala sobre a especificidade da morte nas câmaras de gás, e que não é tanto a industrialização da morte, "senão o desaparecimento total desse frente a frente do assassino e de sua vítima, um desaparecimento que constitui uma negação do crime no interior do próprio crime" (Vidal-Naquet. Cit. Lindeperg, 2009: 66).

Peter Pál Pelbart nos agracia com um insight exemplar sobre Shoah:

Daí porque em Lanzmann temos apenas a Voz e a Terra cruzando o Rosto, e um rosto, como o mostrou Lévinas, diz sempre Não Matarás. Por um lado, as palavras e narrativas que evoluem numa cascata de precisões, hesitações, buracos, recusas, contradições, gagueiras; somos tomados pelas vozes nos vários idiomas (hebraico, polonês, inglês, francês, alemão etc.) e elevados, como por uma Babel do espírito, para um plano de afecções indizíveis, onde a linguagem atinge o seu limite. Por outro lado está a Terra que vemos na tela, e a Terra é a massa pesada que enterrou os cadáveres, o sangue, os vestígios, as colheres, as lembranças, o passado. Assim, ouvimos o nome de Treblinka com seu cortejo de suplícios, mas vemos o prado verdejante ou florido de Treblinka, hoje, e ficamos perturbados, pois o horror do que está sendo dito pela Voz não está sendo visto na Terra, o que a Voz emite, na sua forma etérea, a Terra apagou na sua materialidade bruta, nela vemos outra coisa, as árvores, as rochas, a neve, o rio, vemos a Natureza na sua altiva indiferença. E o ato de fala, como uma resistência obstinada, tenta arrancar à terra aquilo que ela enterra. (Pelbart, 2000: 175).

A Terra, a Voz, o Rosto. E o que há nos perpétuos planos circulares de Shoah? O que nos diz esses giros sempiternos dessa escolha formal e estética de Lanzmann? Talvez nos digam sobre a sensação cíclica da experiência concentracionária; talvez nos contem sobre o "eterno retorno" dos tempos e das imagens genocidárias. Talvez tentem mostrar, como escreveu Jean Cayrol ${ }^{12}$ para as imagens de Noite e neblina, que o solo preenchido pela terra fértil e

12. Jean Cayrol foi um poeta e sobrevivente francês capturado e mandado ao campo de concentração de Mauthausen-Gusen em 1942. A pedido pessoal de Alain Resnais, ele escreveu o belo texto de Noite e neblina (cuja narração é de autoria de Michel Bouquet). 
pela vida esverdeada da natureza, foi o mesmo que testemunhou e engoliu os restos de tantas vidas humanas dizimadas pelo nazismo, e que possivelmente os cadáveres humanos enterrados neste solo, em seu inevitável processo de decomposição, tenham servido para "adubar" a terra onde hoje as imensas árvores, plantas e pastos se encontram.

As imagens a partir da memória e da palavra que Shoah nos concede dos campos de extermínio, transformam-se em relatos testemunhais da ideia potencializada pelo nazismo de aniquilar todo e qualquer rastro da catástrofe. Lanzmann parece desejar descobrir o passado a partir das imagens do presente. Foi essa vontade de dar uma visibilidade à Shoah que precisamente o filme Shoah realiza: nas imagens invisíveis da morte que jamais nos são mostradas, Lanzmann executa um renascimento da presença do horror que, em sua materialidade, inscreve-se no corpo dos sobreviventes, devolve a estes corpos "uma conexão com o mesmo trauma para recuperar o passado como alucinação" (Cangi, 2003: 143), e que a evocação do passado pela memória e pela palavra no filme é mais um vestígio de que para estas testemunhas, (sobre)viver só foi possível por causa da ferida silenciada, e da recusa em inúmeros momentos, em reviver a memória da dor. E é justamente nesta lacuna do dizer, em que a lembrança mesma se posta como gesto testemunhante, que o testemunho diante da catástrofe, o seu relato, abre esta fissura, este vácuo inevitável onde reside sua sobrevivência, sua resistência à aniquilação, ao esquecimento.

Shoah não se desfaz do riso (de Srebnik) e das lágrimas (de Bomba ou Müller ${ }^{13}$ ) para limitar-se ao desejo de compreender, ao contrário, o filme de Lanzmann, a partir dos traços do horror presentificados nos rostos das testemunhas, faz irromper o riso (de loucura?) e as lágrimas (a mais profunda tristeza) de diversos dos sobreviventes, porque, no momento em que o cineasta exige que eles relembrem, um peso descomunal acaba por emergir nas costas destas testemunhas e desvendamos neste exato momento como todas as suas estruturas musculares no instante da lembrança são absolutamente modificadas. É aquele tempo genocidário que impõe à memória uma lembrança, e quando as testemunhas em Shoah retornam no tempo memorial, risos e lágrimas se tornam gestos sobrecarregados de uma dor crepuscular e os rostos enlutados pelos mortos intermináveis já não conseguem mais ser normalizados, mas antes, o que os contaminam, na raiz venosa dessas faces, é o medo e a dor de lembrar, de não conseguir conter (por causa da vergonha, do trauma, do horror) o choro (ou o riso), que para estas testemunhas é o desabrochar mais íntimo do peso dessa memória, desse horror lacerante.

13. Falaremos mais adiante sobre estes dois personagens (Abraham Bomba e Philip Müller) que são apresentados no filme. Dois testemunhos impressionantes, e onde as lágrimas, depois de muita resistência, acabam por desaguar de forma devastadora em ambos. 
Herik Gawkowski (fig.3), aparece no filme fazendo o mesmo ofício que executara na época do domínio nazista: sendo o maquinista responsável por levar mais uma leva de judeus nos vagões dos trens para o campo de extermínio de Treblinka ${ }^{14}$. Polonês, Gawkowski, ao retornar ao trem de antanho com Lanzmann e dirigir a locomotiva, acredita fielmente estar revivendo na pele aquele passado ${ }^{15}$, fazendo-o repetir maquinalmente o gesto aterrorizante da degolação (fig.4), quando o trem se aproxima do campo, e onde, ainda hoje, a placa com o nome Treblinka permanece. É inclusive a imagem de Gawkowski, segundo antes de fazer o gesto simbolizador da morte, que estampa a capa das versões em home vídeo de Shoah.

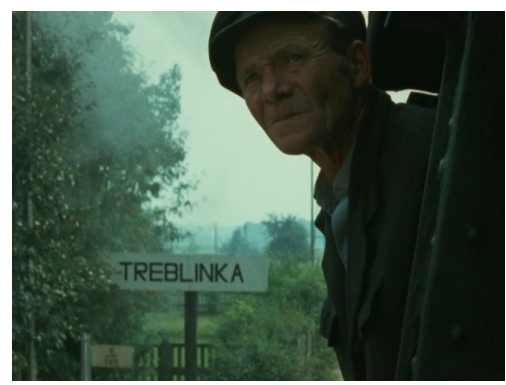

Figura 3. Gawkowski, e a placa de Treblinka

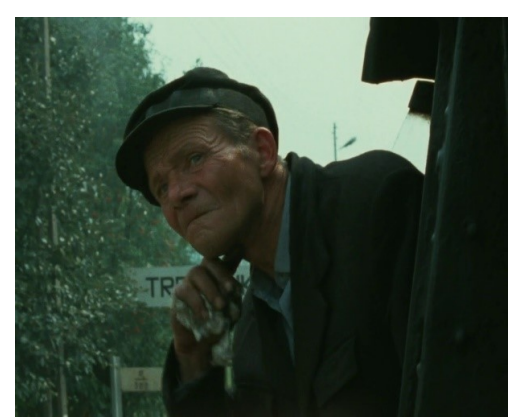

Figura 4. Ele fazendo o gesto da degolação.

14. Estima-se que entre setecentos a novecentos mil judeus foram exterminados em Treblinka, que foi o campo de extermínio, depois de Auschwitz-Birkenau, onde mais morreram seres humanos.

15. Alucinação semelhante ocorre em S-21 - A máquina da morte do Khmer Vermelho (2003), de Ryth Pahn, quando um antigo membro do exército genocida do Khmer Vermelho (responsável pela morte de mais de um milhão e duzentas mil pessoas no Camboja, equivalendo ao extermínio de mais de um terço da população do país) acaba por acreditar que realmente está vigiando e torturando presos, quando na realidade deveria apenas realizar uma encenação de como era o seu procedimento quando membro do exército genocida. 
O momento do depoimento de Abraham Bomba (fig.5), judeu e cabelereiro responsável por "arrumar" os deportados minutos antes dos mesmos entrarem nas câmaras de gás, revela-nos um minúsculo rastro do extermínio perpetrado pelo nazismo. Bomba era

o último homem na linha da morte, a voltar a cortar cabelo e recordar, submetido às perguntas de Lanzmann, enfrenta em sua memória o momento-limite do silêncio e afeto para com alguns conhecidos de seu povoado, aos que não pôde conter antes de entrarem enganados à câmara de gás. (Cangi, 2003: 146).

Importante perceber que quando Lanzmann entra na barbearia onde Bomba trabalha, o sobrevivente parece irritado, monossilábico - e quando fala quase nega a própria voz. LaCapra, por esta cena, critica o desvio histórico e documental do filme, que segundo o historiador americano, neste momento, Shoah é deslocado do sentido originário e histórico de seus primeiros minutos:

Abraham Bomba analisa seu papel como cabelereiro em Treblinka enquanto ele corta o cabelo de alguém. O espectador fica impactado ao entrar e ver o salão cheio e quem ali estava eram simples clientes que não compreendiam a linguagem (inglês) que que Lanzmann e Bomba dialogavam. Mais ainda, uma de minhas principais preocupações é que as dimensões históricas de Shoah sejam questionadas. $\mathrm{O}$ espectador espera que o filme seja histórico e inclusive documental. Na verdade, essa expectativa é gerada pelo prólogo narrativo que introduz o filme ao analisar em termos fatuais o campo de extermínio de Chelmno. Portanto, o subtítulo da versão inglesa da obra, Na Oral History of the Holocaust, adequava-se às expectativas plausíveis de espectadores ou leitores. (Lacapra, 2009: 116).

Sobre este complexo momento entre Bomba e Lanzmann, o segundo escreveu:

Voltou interessante o momento em que, na segunda parte da entrevista, repeti o mesmo, ainda que diferentemente, quando voltei a colocá-lo na situação dizendo: "O que fez? Imite os gestos que fez". Pegando o cabelo de seu cliente (que haveria de ter cortado fazia tempo, se realmente estivesse concentrado em cortar, já que a cena durou vinte minutos). E a partir desse momento a verdade se encarnou e ele revive a cena, colocando o conhecimento já encarnado. Na verdade se trata de um filme sobre a encarnação. (Lanzmann, 1992: $301)$.

Se o filme, nas palavras de Lanzmann, é uma obra sobre a encarnação, uma das modalidades encarnadas pelo cineasta francês reside justamente no espectro inquisidor que ele vai impor aos sobreviventes (sobretudo a Bomba), a saber: obriga-los de qualquer maneira a trespassar a linha limite da memória da dor, a esta memória que enquanto gesto do testemunho tem a sua lacuna no emergir do silêncio, na impossibilidade da fala, onde a testemunha à luz de sua própria incapacidade de contar se depara com a inquisição do Outro que 
a obriga a dizer o que não deveria (ou poderia) ser dito, a conceder uma imagem a partir de uma mise en scène catastrófica daquilo intrinsicamente amorfo, portanto, não teatralizável. É esta encarnação mesma que acaba por transformar Bomba em uma espécie de ventríloquo de Lanzmann ${ }^{16}$, o que tem uma consequência devastadora, quando a ser novamente sequestrado para dentro de si mesmo, Bomba é completamente desfeito em lágrimas, e rememora o momento em que se depara com mulheres e crianças conhecidas de sua aldeia prestes a terem seus cabelos cortados por ele para logo após entrarem nas câmaras de gás (que os nazistas, para evitar o desespero, mentiam dizendo que os prisioneiros iriam para aquele local para serem desinfetados de piolhos e outras pragas). As mulheres da aldeia reconhecem Abraham, e perguntam o que ocorrerá a elas, e ele para sobreviver permanece em um silêncio assolador, e apenas realiza o seu ofício de cabelereiro.

O homem devastado pela lembrança, irrompendo em pranto, com o soluço de dor rasgando a sua garganta; esta é a imagem última que o filme captura de Bomba. Os estilhaços de sua presença nos permite imaginar aquilo que já não existe em imagens: os gritos sufocados pelo gás venenoso Zyklon $B^{17}$, os socos desesperados desferidos na porta principal da câmara de gaseamento, implorando para que ela fosse aberta. Bomba testemunhou tudo isso que, hoje, somente a imaginação pode supor. E não pôde fazer nada. Seu testemunho em Shoah é uma greta sem fim, é aquilo que disse Spinoza (1990) sobre a tristeza cujo terror impede a alma de pensar, e como é triste reduzir o que pode um corpo, sua potência, como direito natural.

16. No sentido que François Cooren deu à encarnação (e ao ventríloquo), isto é, que a interação com a fala do participante (no nosso caso é Bomba) acaba por conceder um poder desconhecido ao mesmo: "Através de figuras específicas que vêm para serem encarnadas ou não, para uma outra próxima primeira vez, através da interação da fala do participante [...] implicitamente ou explicitamente as figuras invocam a permissão dos participantes em fazer de si mesmos mais poderosos através da autoridade que essas tantas figuras conferem a eles" (Cooren, 2010: 141).

17. Originalmente um pesticida a base de ácido cianídrico, cloro e nitrogênio, inicialmente usado nos deportados para combater piolhos, e posteriormente, utilizado para o extermínio em massa nas câmaras de gás. Outro detalhe importante: Zyklon em alemão significa ciclone. 


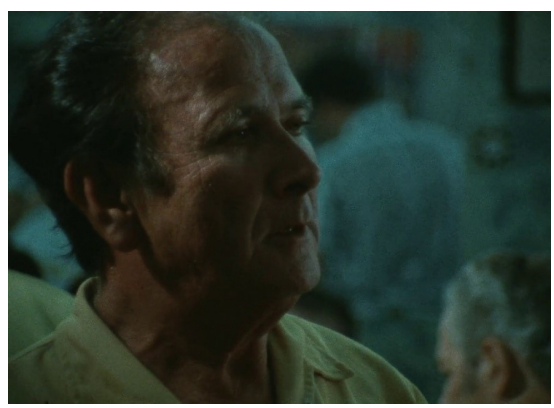

Figura 5. Abraham Bomba.

E por fim entre os sobreviventes, existe Philip Müller. Sobre ele, LaCapra pontua:

O antigo membro do Sonderkommando Philip Müller mostra um estilo narrativo tradicional que até certo ponto traduz sua desconcertante história a uma forma conciliatória e modulada. Parece falar contando seu relato muitas vezes antes e se mostra capaz de atuar com o virtuosismo de um narrador experiente, até quase converte-se em um bardo do último desastre. Lanzmann não faz nada para interromper o relato de Müller e se mostra como uma escuta paciente e atenta. A narração somente se detém quando Müller chega a um ponto de ruptura ao relatar que seus compatriotas a bordo da morte no "quarto para se despir" começam a cantar o hino nacional tcheco e Hatikva. ${ }^{18}$ (Lacapra, 2009: 126).

O "ponto de ruptura" que diz LaCapra é quando Müller desaba em choro (em um dos momentos mais poderosos de todo filme) ao relembrar o exato momento da "revolta" desses deportados, e a recusa em tirarem suas roupas. Sobre esse instante, o próprio Müller relata:

A violência culminou quando eles (os SS) quiseram força-los a despir-se. Alguns obedeceram, um punhado apenas. A maioria recusou executar essa ordem. E de súbito, foi como um coro. Um coro... Começaram todos a cantar. O canto encheu o vestiário inteiro, o hino nacional tcheco, depois a Hatikva ressoaram. Aquilo me comoveu terrivelmente. (Müller. Cit. Lanzmann, 1987: 218).

Com lágrimas nos olhos, Philip testemunha (figs.6 a 9):

Era os meus compatriotas que aquilo acontecia... e percebi que minha vida não tinha mais nenhum valor. Para que viver? Por quê? Então entrei com eles na câmara de gás, e resolvi morrer. Com eles. De repente vieram até mim alguns que me haviam reconhecido. Pois várias vezes, com meus amigos serralheiros, eu fora ao campo das famílias. Um pequeno grupo de mulheres se aproximou. Elas me olharam e disseram-me: “Já na câmara de gás?”. [...]

18. Hino nacional de Israel. 
Uma delas me disse: "Então você quer morrer. Mas isso não tem nenhum sentido. Sua morte não nos devolverá a vida. Não é um ato. Você precisa sair daqui, deve testemunhar o nosso sofrimento, e a injustiça que nos foi feita”. (Müller. Cit. Lanzmann, 1987: 218-9).
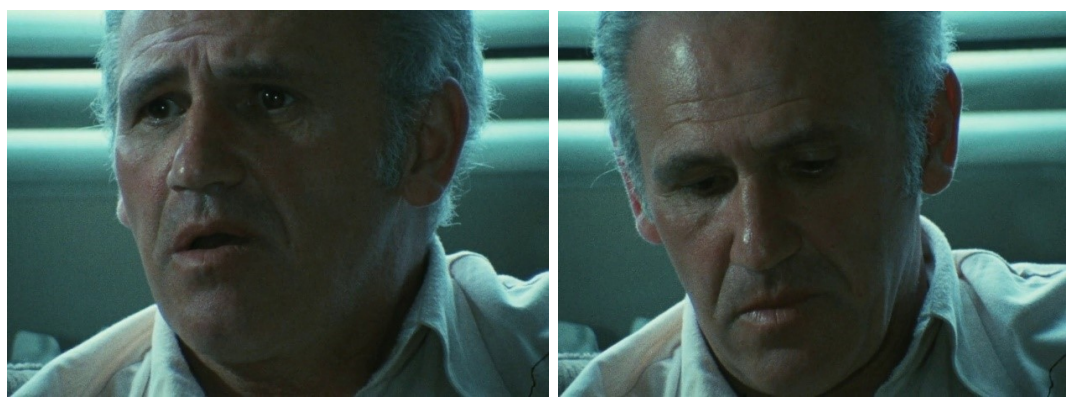

Figuras 6 e 7. Müller ainda conseguindo resistir...
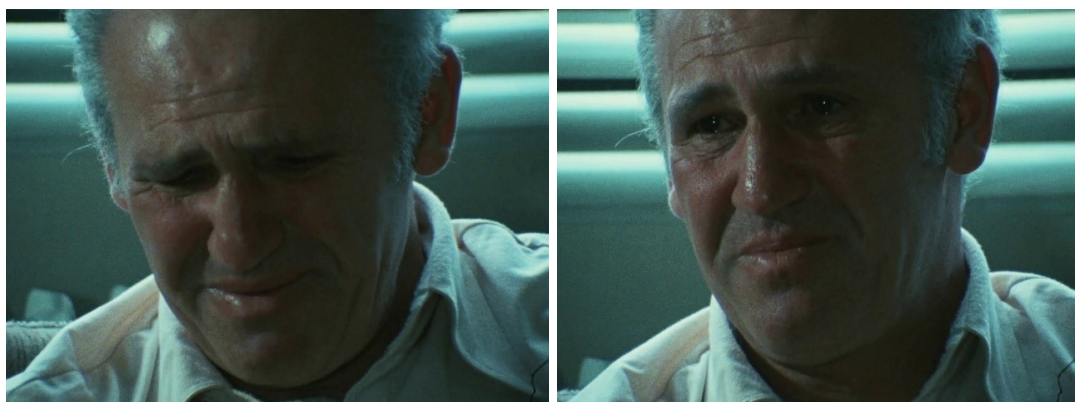

Figuras 8 e 9. Mas logo em seguida desata em pranto por causa da memória da dor.

É este local da morte, que como desejou Benjamin (1994), é o local de excelência do narrador e de onde Müller e tantos outros sobreviventes falam - mas que não narram as suas histórias particulares. É sempre uma narração sobre os outros que não conseguiram escapar, e que para não ser consumido pela própria loucura ${ }^{19}$ e solidão de uma memória catastrófica, a testemunha em Shoah sempre fala do Outro que sucumbiu. É tocante e fundamental as palavras que uma mulher diz a Müller já dentro da câmara de gás: "Você precisa sair daqui, deve testemunhar o nosso sofrimento, e a injustiça que nos foi feita", ele que "recebe de sua própria gente o impulso de sobreviver" (Cangi,

19. Como escreveu o historiador francês Pierre Vidal-Naquet (1995: 29) sobre Shoah, que na intenção do filme contém um "elemento de loucura: ter feito uma obra histórica em uma conjuntura de qual somente se chama a dar testemunho a memória, uma memória atual". 
2003: 143), esta essência da sobrevivência que exige que a testemunha fale, foi a mesma que dominou a presença de Hermann Langbein e a sua necessidade de resistir à morte para justamente testemunhar sobre o horror nazista que ele vivenciou:

De minha parte, tinha decidido firmemente que, independente do que me viesse a acontecer, não me teria tirado a vida. Queria ver tudo, viver tudo, fazer experiência de tudo, conservar tudo dentro de mim. Com que objetivo, dado que nunca teria tido a possibilidade de gritar ao mundo aquilo que sabia? Simplesmente porque não queria sair de cena, não queria suprimir a testemunha que podia me tornar. (Langbein. Cit. Agamben, 2008: 25).

Por que é tão difícil para o sobrevivente falar ou nomear a sua própria história? Claude Lanzmann teoriza a partir de uma "impossibilidade de voltar a contar a história", e que colocando esta impossibilidade no começo de seu filme, é justamente porque por um lado em Shoah há uma "desaparição dos rastros", "já não resta nada. Não há nada (le néant)", e que ele, portanto, deveria "fazer um filme partindo desse nada". Assim:

por outro lado, estava a impossibilidade dos próprios sobreviventes em contar esta história, a impossibilidade de falar, a dificuldade - que se percebe ao longo de todo o filme - de dar nascimento à coisa e à impossibilidade de nomeá-la: seu caráter inominável. É por isso que foi tão difícil encontrar um título (para o filme). (Lanzmann, 1992: 295).

A coisa. Nomeá-la. Antes do filme Shoah, a catástrofe nazista era chamada pelos rabinos de justamente "A Coisa", e que o sobrevivente Elie Wiesel batizou (equivocadamente) de Holocausto ${ }^{20}$. A força do filme, sua importância, está no maelstrom das memórias que o filme resgata, nestas lembranças mesmas que nos permitem imaginar as imagens possíveis deste momento limítrofe da condição humana.

O extraordinário testemunho que Shoah nos concede é justamente o traço do horror nazista que as vozes, na incandescência espectral do esquecimento impossível, transmitem a partir da imagem cinematográfica, em seu movimento que ao vitalizar o testemunho, penetra-nos com uma pulsão da morte inevitável a tais relatos. É neste irromper a partir do horror que o filme rapta aqueles que o assiste, leva ao abismo da dor o espectador, que uma vez diante das imagens e dos fragmentos de memória resgatados, torna-se testemunha ao mesmo tempo do poder perpétuo que a imagem de cinema tem em registrar a

20. Termo que, como fica explícito no nosso texto, não fora por nós utilizado devido a sua origem etimológica de uma oferenda às divindades, dando espaço assim, para a proliferação daqueles que defendem a Shoah (não só o filme, mas toda a catástrofe) como um acontecimento irrepresentável, inimaginável e sem imagens possíveis. Para maiores detalhes, ver $O$ que resta de Auschwitz de Giorgio Agamben. 
eternidade dos rostos, como da lâmina flamejante a queimar infindavelmente a história humana após Auschwitz.

\section{Do irrepresentável (e inimaginável) à abjeção do arquivo}

A grandeza de Shoah enquanto cinema nos parece incontestável, e a sua marca histórica - este peso da matéria e da presença humanas - em mais de uma década de pesquisa e completa doação física e emocional de seu realizador, Claude Lanzmann, inscreve o filme à luz de uma história particular das vozes do testemunho, dos rostos rasgados ao lembrar, da dor mesma da memória, das paisagens verdes onde outrora o corpo humano, e sobretudo, a ideia mesma de humanidade foram exterminados. Porém, anos após seu lançamento, Shoah e Lanzmann acabaram por teorizar uma ideia que entra no caminho do absoluto: que a catástrofe nazista é irrepresentável e inimaginável, e que, portanto, não existem imagens possíveis deste momento genocidário. Ao mesmo tempo que traça este caminho ao absoluto, Shoah e Lanzmann repudiam a ideia do uso do arquivo, o que nos leva a pensar algo sobre a abjeção, e como esta ideia abjeta para a imagem-arquivo reside concomitantemente a partir de uma arrogância intelectual e de uma descrença de que toda imagem ao seu fim (mesmo diante de sua eternidade), tornar-se-á arquivo, vestígio da história.

Georges Didi-Huberman, em Imagens apesar de tudo, um dos livros mais importantes sobre justamente a importância tanto da representação e imaginação da Shoah - como da necessidade histórica da imagem-arquivo -, constrói uma obra a partir de um ataque da tríade de intelectuais franceses ${ }^{21}$ que de forma irredutível defende a Shoah (a catástrofe) como um acontecimento sem imagens, e que Shoah (o filme) é toda a imagem existente, é todo o cinema único e possível que pode dar algum tratamento ao genocídio perpetrado pelos nazistas. Qualquer outra imagem para além do filme é motivo de desprezo e recusa por parte destes intelectuais. De outro modo, filmes como Noite e neblina, A Dor e a piedade (Marcel Ophüls, 1969), os arquivos de filmagens dos campos de concentração nazistas realizados por Samuel Fuller ou George Stevens, as exposições fotográficas com imagens reais de dentro do horror concentracionário, para a tríade francesa, não possui valor ou importância histórica, o que

21. Claude Lanzmann, Gérard Wajcman e Élisabeth Pagnoux com as publicações na revista Les temps moderns, Março-Maio, 2001. O livro original de Didi-Huberman (Images malgré tout) foi lançado em 2004. A polêmica com a tríade francesa começou com o ensaio idêntico ao do livro escrito por Didi-Huberman para o catálogo da exposição Mémoire des Camps: Photographies des Camps de concentracion et d'extermination nazis (1933-1999), organizado por Clemant Chéroux, onde falava da importância testemunhal de quatro imagens obtidas pelo Sonderkommando de Auschwitz, "seleção" de presos judeus que tinham a visão final do extermínio. 
nos leva a constatar em sobressalto que, de fato, estamos diante de uma ideia de irreversível abjeção ao arquivo.

Com um dos mais famosos polemistas, o psicanalista francês Gérard Wajcman, Didi-Huberman (2012: 121) diz que ele exagera previamente o inimaginável, afirmando que Wajcman acha que o filme Shoah consegue mostrar "o que nenhuma imagem pode mostrar, (uma vez que este) mostra que existe algo como o Nada a ver (e que) o que isso mostra é que não há imagem". DidiHuberman aponta uma aporia para esta concepção de seu polemista: a cega e a paradoxal. A consequência cega para o filósofo e historiador da arte francês seria a impossibilidade de Wajcman ver a imagem por vir ("Se há Shoah, então não há imagem por vir"); a consequência paradoxal emerge quando Gérard Wajcman diz que mesmo sem ver o filme de Claude Lanzmann, mas apenas pela sua existência, seria suficiente para cada ser humano ser hoje uma "testemunha da Shoah".

Claude Lanzmann, desafeto declarado de Didi-Huberman ${ }^{22}$, tem uma ideia própria e absoluta do que é ou deve ser o testemunho, a representação e o arquivo da Shoah. Ideia que Pagnoux e Wajcman retransmitem sem pes$\operatorname{tanejar}^{23}$. Lanzmann ao absolutizar a catástrofe nazista para dentro de seu próprio filme (que como já dissemos, é extraordinário, mas jamais pode ser tudo) acaba por suprimir vestígios fundamentais da história, de um tempo genocidário que legou ao mundo uma perpétua exigência de interpretar todas as imagens e testemunhos. Imaginar, representar não é dar sempre um passo adiante para implodir cada vez mais a ideologia nazista (totalitária) de aniquilação de toda imagem e de toda a presença humana? Não é ir, sempre, ao socorro de todo vestígio que venha a aparecer, e a partir desta aparição, reelaborar toda uma história por mais fissurada que ela seja? Imaginar, portanto, não seria permitir que toda imagem, por mais frágil, por mais lacunar, viesse nos tocar?

E é justamente nesta tentativa de elaborar novos traços possíveis (tocar e ser tocado pela imagem) onde a importância do arquivo reside. Mas o caso de Shoah, ou melhor, de seu realizador e de seus defensores, condensa-se em uma ideia de desprezo e negação desta presença do arquivo, a saber: Lanzmann não consegue aceitar a ideia mínima de uma imagem, de uma presença mesma, que

22. Durante a nona edição da Festa literária internacional de Paraty (Flip) em 2011, Márcio Seligmann-Silva enquanto mediador do debate com Claude Lanzmann, citou o nome de DidiHuberman, causando um grande mal estar com esse convidado, que ao ameaçar deixar a mesa, chamou o filósofo francês de "imbecil" (Seligmann-Silva, 2011).

23. "Tudo aquilo que Wajcman e Pagnoux acharam oportuno repetir [...], contra a análise das quatro imagens de Auschwitz, não era senão uma conscienciosa repetição das teses defendidas pelo cineasta (Lanzmann) acerca da sua própria concepção da imagem, do arquivo e do testemunho" (Didi-Huberman, 2012: 122). 
possa vir a sequer dialogar com as "imagens absolutas" de seu filme. Mas o que isto diz? A que se deve esta abjeção ao arquivo e a imagem que ele marca?

Vejamos:

As imagens de arquivo são imagens sem imaginação. Elas petrificam o pensamento e matam todo o poder de evocação. Vale bem mais fazer o que fiz, um imenso trabalho de elaboração, de criação da memória do acontecimento. O meu filme é um 'monumento' que faz parte daquilo que monumentaliza como diz Gérard Wajcman. [...] Preferir o arquivo fílmico às palavras das testemunhas, como se pudesse mais do que estas, é reconduzir sub-repticiamente esta desqualificação da palavra humana na sua destinação para a verdade. (Lanzmann, 2001: 274).

Ora, chamar as imagens de arquivo de imagens sem imaginação? Não seria justamente o contrário aquilo que tais imagens podem proporcionar? Diante da precariedade do espaço e do tempo onde a sua existência aconteceu, a imagem-arquivo da catástrofe nazista nos convida a driblar esta petrificação do pensamento que diz Lanzmann, exige de nós que para nos desvencilharmos de certas manias estéticas, penetremos nos poros do celuloide, nos minúsculos vestígios de sombras e marcas do tempo e da morte para, exauridamente, restituirmos um significado, uma imaginação mesma do espectro e da penumbra do Lager. Ou como se pergunta Didi-Huberman tendo em mente a citação acima de Lanzmann:

E por que razão construir um "monumento", atendendo a como o próprio Lanzmann qualifica o seu trabalho, teria de equivaler a desqualificar os "documentos" sem os quais o monumento se erige no vazio? Por que razão assumir o tom de "lenda" - "tal é o que me permite dizer que o filme é imemorial" - e recusar, juntamente com a "'legenda" necessária às fotografias de arquivo, todo um campo de memória? (Didi-Huberman, 2012: 124).

Não é diante do arquivo mesmo que uma história de imagens deve ser iniciada? O próprio filme Shoah tem pelo menos um momento "arquivista" fundamental, quando Lanzmann, emulando a aura do judeu Alex (o membro do Sonderkommando que em Auschwitz captura secretamente as imagens sobreviventes), grava em segredo uma entrevista com Franz Suchomel (figs. $10 \mathrm{e}$ 11), um dos líderes ss responsável pela ordem do campo de extermínio de Treblinka e pelos eventos do programa da eutanásia nazista. Em completo sigilo Lanzmann filma as respostas de Suchomel para as suas perguntas. A qualidade precária da gravação nos permite buscar paralelos com as fotos do judeu Alex (fig.12) em Auschwitz: ambas as capturas à luz da história acabaram por se tornar partes basilares da compreensão de um mundo genocidário a partir de imagens realizadas em absoluto segredo, este silêncio onde a imagem em sua execução clandestina acaba por antecipar (a morte, para Alex; a mentira, para Suchomel) alguns dos modi operandi do nazismo. 

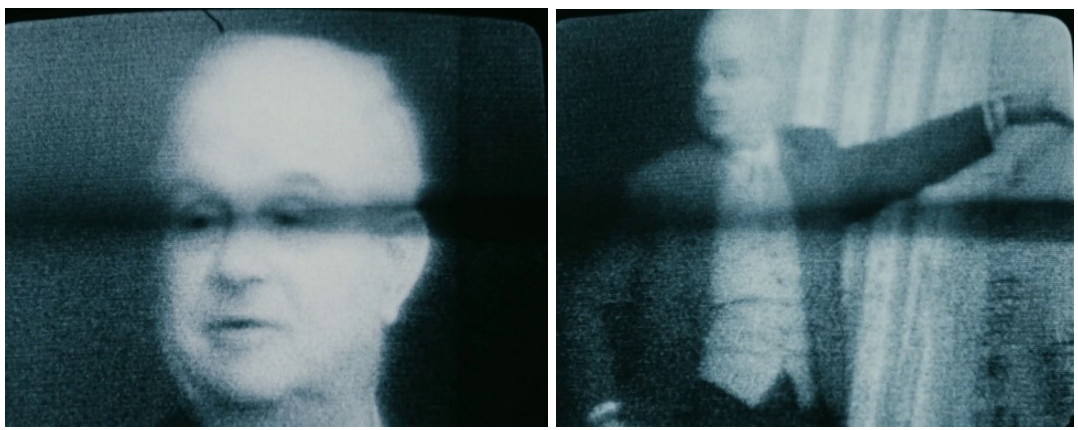

Figuras 10 e 11. Suchomel filmado clandestinamente por Lanzmann.

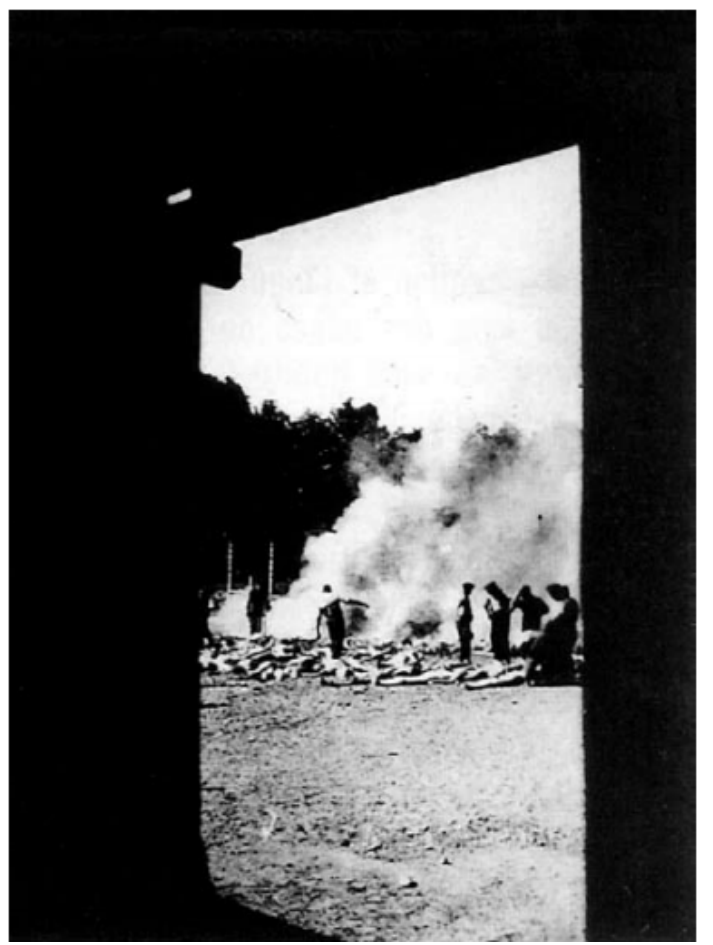

Figura 12. A foto original feita pelo judeu grego Alex.

Suchomel, o burocrata perfeito, o homem que apenas cumpre a sua função profissional. Quando colocado contra a parede por Lanzmann, em sua língua materna, engasga, respira fundo, a fala ora gaguejada ora cômica não consegue esconder uma perspectiva gélida sobre a vida humana. Esta imagem escondida 
que Lanzmann oferece ao mundo tem, no momento de sua sobrevivência arquivista, aquilo que Arlette Farge (2009) disse sobre o sentido inesgotável das profundezas e do mistério do arquivo; e petrificando a fisionomia de Suchomel, a filmagem clandestina de Lanzmann possibilita não somente que olhemos para o oficial nazista e sua burocracia naturalizada pelo horror, mas que a imagem-arquivo também nos olhe, cravando no mundo a partir deste momento a sua inegável importância histórica. Esta filmagem de Lanzmann é um procedimento que "se assemelha na verdade ao do andarilho, buscando no arquivo o que está escondido como vestígio positivo de um ser ou de um acontecimento, estando atento simultaneamente ao que foge, ao que subtrai e se faz, ao que se percebe como ausência" (Farge, 2009: 71). Não seria exagero afirmar que tanto Alex quanto Lanzmann executam, cada um à sua própria maneira, um gesto clandestino.

Este momento de sabor clandestino e arquivista no filme "sem arquivos" de Lanzmann acaba por legitimar a nossa ideia, a ideia de que o fim cíclico de toda imagem (por mais eterna que ela seja) é tornar-se excerto da história, arquivo daquilo que ela testemunha. E Shoah não é hoje um imenso arquivo testemunhante, que no rasgo da palavra e da memória, possibilita-nos ver e imaginar apesar de tudo novas imagens e novos fantasmas para a catástrofe nazista? Shoah é imagens, é um testemunho concedido pelo cinema. Shoah é arquivo justamente porque o seu testemunho reside nas imagens que já não podem mais desaparecer.

\section{A radicalidade da morte}

Olhar os testemunhos em Shoah, ou seja, escutar as pradarias que embora esverdeadas guardam em seu ventre todo um horror é também resistir à agonia verdejante (quase acinzentada) dos rostos e presenças que são capazes, dentro do filme de Lanzmann, de invocar suas vozes para justamente evocar a memória duplicada da sobrevivência (morte e vida; lembrança e esquecimento). Diante da aporia que toda sobrevivência (Nachleben) porta em seu destino, a que faz corromper quase toda a recordação da Shoah é justamente a ideia de aniquilação absoluta do homem e de todo o seu vestígio humano que o nazismo perpetrou em seus campos da morte. Esta radicalidade da morte é então o antro (para muitos equivocadamente sustentado de inominável, inimaginável) onde a imagem nazista fundou seu procedimento de extermínio.

Diante desta radicalidade da morte é na sobrevivência, este gesto radical, onde revela-se a pegada inestimável da memória: lembrar de que nesta radicalidade da morte se concentra todo o horror, toda a essência do genocídio do Terceiro Reich. E a própria etimologia da palavra radicalidade concede 
ao mesmo tempo a ideia de algo pertencente à raiz (isto é, a este mundo, a esta terra: a vida humana) e de uma inerência, de algo justamente inseparável de todo procedimento, de toda execução (os métodos nazistas de extermínio). Radicalidade, portanto, enquanto aporia (como é toda sobrevivência): como aquilo que desprende a vida enraizada de sua terra, ao passo que radicalmente extermina essa mesma vida enraizada sem piedade em todo o seu vestígio, em todo o seu fundamento, em toda sua raiz.

Como foi possível realizar o que o nazismo realizou, em seus campos da morte, com o homem - com toda sua humanidade? Saul Friedländer sonda assim:

Aqui há algo que nenhum outro regime tentou fazer, sem se importar com qual fosse o crime. Neste sentido, o regime nazista alcançou uma classe de limite teórico exterior. É possível considerar inclusive maior número de vítimas e meios de destruição tecnologicamente mais eficazes; mas quando um regime com base em seus próprios critérios, decide que existem grupos que não possuem o direito de viver sobre a terra, assim como o lugar e o prazo de seu extermínio, então já foi alcançado o umbral extremo. A partir de meu ponto de vista, este limite não foi alcançado mais do que uma única vez (only once) na história moderna, pelos nazistas. (Friedländer, 1993: 82).

Um limite genocidário que não ocorreu "mais do que uma única vez na história moderna". Então não é somente sobre a radicalidade da morte que um filme como Shoah tenta apesar de tudo nos mostrar, mas o filme de Lanzmann também nos faz ver que esta radicalidade mesma é composta por uma singularidade, isto é, por um momentum inimitável, intransponível ao símbolo da suástica, à imagem mesma de Hitler e de seu Terceiro Reich.

O grande historiador italiano Enzo Traverso levanta justamente esta ideia de Auschwitz singular, onde reside na singularidade dos campos de extermínio (como eram Auschwitz, Chelmno, Treblinka entre outros) toda a diferença, ou seja, toda a singularidade quando comparado aos campos de concentração nazistas (Bunchewald, Dachau, Bergen-Belsen entre outros):

Os campos de extermínio nazistas se converteram no símbolo desta singularidade que distingue tanto o genocídio judeu de outros tantos crimes cometidos pelo próprio nazismo, como das violências do estalinismo. Bunchewald e Kolyma seguem sendo universos de morte, mas a morte não era sua finalidade imediata, melhor dizendo, era a consciência de um processo mais lento de extermínio mediante o trabalho. (Traverso, 2004: 3).

Shoah possibilita que imaginemos apesar de tudo os campos de extermínio, toda a sua singularidade (aniquilar ao homem em um único instante através das câmaras de gás, e fazê-lo desaparecer nos crematórios, opondo de certo modo à operação existente nos campos de concentração, onde o trabalho escravo era algo normatizado e as grandes empresas alemãs, brutalmente, tiravam provei- 
tos desta mão de obra escravizada), e toda sua radicalidade (fazer da morte algo extremo; exterminar milhões de vidas em uma mesma geografia; arrancar todo o vestígio humano pela raiz).

\section{Considerações finais}

Quando avistamos os personagens em Shoah não há justamente em suas fisionomias uma singularidade (estes rostos que sustentam uma memória da dor, uma dor que quase os tornam loucos e que só pôde existir em um campo nazista) ao mesmo tempo que uma radicalidade (ou seja, que embora face à morte extrema as testemunhas puderam sobreviver, e mesmo testemunhando todo o sentido humano sendo arrancado pela raiz, foram capazes, no filme de Lanzmann e em uma imensa literatura sobre a Shoah, de contar apesar de tudo suas histórias impressionantes). Não há na sobrevivência mesma, neste Nachleben, toda uma radicalidade da resistência (da sobrevida) para suportar a radicalidade da morte perpetrada nos campos nazistas? Não reside no gesto radical de sobreviver o único modo possível para aqueles homens e mulheres contarem um vestígio, uma fração improvável do horror que eles viram?

Shoah de Claude Lanzmann é portanto este imenso filme sobre a sobrevivência do corpo do homem e de seu vestígio humano. Sobrevive porque como apontado por Maurice Blanchot (2003) o homem é o indestrutível, embora possa ser eternamente destruído; ou como por Jean-Luc Nancy (2003) quando diz que é por sua impenetrável resistência à aniquilação que o homem é tornado absoluto. Ou seja, o homem é indestrutível apesar de sua destrutibilidade, inaniquilável apesar de sua aniquilabilidade. Shoah nos dar a ver estas "histórias de corpos e de desejos, histórias de almas e de dúvidas íntimas durante a grande derrocada, a grande tormenta do século" (Didi-Huberman, 2011: 82). Histórias de corpos, de desejos. Uma história, portanto, sobre a esperança, sobre a luz apesar de tudo.

Toda esperança, toda luz advinda das testemunhas em Shoah parece gemer. Geme para que consigamos ver melhor toda a dor que a escuridão da memória do nazismo instaurou na história do mundo - assim, o filme retira da escuridão os seus rostos humanos. Geme para que essa mesma esperança, essa luz, possam ser avistadas em todo o horizonte, sem cronologia definida, portanto, um gemer anacrônico. Um gemer que é também choro, o que cristaliza-se em Shoah quando diversas das testemunhas no filme de Lanzmann diante do insuportável peso de lembrar desatam em um pranto profundo, devastador.

Vendo Shoah um abismo parece se abrir, como um terremoto faz ao solo, à terra. Um abismo da perda, da dor, de um luto que apesar de tudo "põe o mundo em movimento" (Fédida, 2004: 138). Mirando as fisionomias no filme 
de Lanzmann faz parecer que toda a vida humana está ameaçada a ser conduzida para tal experiência da morte, dar-nos a ver que toda lembrança é este artefato basilar para que nunca nos esqueçamos do detalhe mais minúsculo de um genocídio. E se o gemido, o choro, a radicalidade da morte e da sobrevivência se repetem constantemente nos testemunhos do filme é justamente porque parece que "somos olhados pela perda, ou seja, ameaçados de perder tudo e de perder a nós mesmos. Talvez esteja aí também o que há de mortal na repetição" (Didi-Huberman, 1998: 86).

Repetição mortal. Repetição sistemática do extermínio que os nazistas impuseram nos seus campos da morte. Shoah traz para a memória de nosso tempo a fagulha da lembrança do horror irrepetível que tocou a humanidade, que fez com que Georges Bataille (1988) escrevesse a sentença de que a partir do nazismo, a imagem do homem está inseparável de uma câmara de gás. E em cada rosto que o filme captura, toda uma esperança na sobrevivência humana emerge, resplandece, apesar de todo sofrimento, de toda humilhação. Saber que o homem saiu vivo da hecatombe nazista é, de fato, (re)descobrir que por mais singular e radical que tenha sido o extermínio nos campos do Terceiro Reich, a vida humana é esta raiz que é capaz de sobreviver mesmo diante de toda a destruição possível.

\section{Referências bibliográficas}

Agamben, G. (2008). O que resta de Auschwitz: o arquivo e a testemunha. São Paulo: Boitempo.

Bataille, G. (1973). La experiencia interior. Madrid: Taurus.

Bataille, G. (1988). Sartre. Paris: Gallimard.

Benjamin, W. (1994). O Narrador: considerações sobre a obra de Nikolai Leskov. In Magia e técnica, arte e política: ensaios sobre literatura e história da cultura (pp. 197-221). São Paulo: Brasiliense.

Blanchot, M. (2003). In the night that is watched over. In D. Dobbels (org.), On the Robert Antelme's the human race: essays and commentary (pp. 55-59). Evanston: The Malboro Press.

Cangi, A. (2003). Imagens do horror. Paixões tristes. In M. Seligmann-Silva (org.), História, memória, literatura: o testemunho na era das catástrofes (pp. 139-169). Campinas: Editora Unicamp.

Cooren, F. (2010). Action and Agency in Dialogue: Passion, incarnation and ventriloquism. Amsterdam: John Benjamins Publishing.

Didi-Huberman, G. (2012). Imagens apesar de tudo. Lisboa: KKYM. 
Didi-Huberman, G. (1998). O que vemos, o que nos olha. São Paulo: Ed.34.

Farge, A. (2009). O sabor do arquivo. São Paulo: Edusp.

Fédida, P. (2004). L'Absence. Paris: Folio.

Friedländer, S. (1993). Memory, History and the Extermination of the Jews of Europe. Indiana: Indiana University Press.

Lacapra, D. (2009). Historia e memoria después de Auschwitz. Buenos Aires: Prometeo Libros.

Lanzmann, C. (1992). Le lieu et la parole. In M. Deguy (org.), Au sujet de la Shoah: le film de Claude Lanzmann (pp. 290-317). Paris: Belin.

Lanzmann, C. (2001). Le monument contre l'archive. Cahiers de mèdiologie, (11): 271-279. Paris: CNRS Editions. Disponível em: http://mediologie.o rg/cahiers-de-mediologie/11_transmettre/lanzmann.pdf.

Lanzmann, C. (1987). Shoah: vozes e faces do Holocausto. São Paulo: Brasiliense.

Lindeperg, S. (2009). Noche y niebla, un film en la historia. Cuadernos de cine documental, 03: 58-73. Santa Fé: Universidad Nacional del Litoral.

Neumann, F. (2009). Behemot. The structure and practice of National Socialism. Oxford: Oxford University Press.

Pelbart, P. P. (2000). Cinema e holocausto. In A. Nestrovski \& M. SeligmannSilva, (orgs), Catástrofe e representação (pp. 171-183). São Paulo: Escuta.

Sánchez-Biosca, V. (2009). Sombras de guerra: las imágenes cinematográficas de la Shoah. Historia Social, (63): 111-132.

Seligmann-Silva, M. (2011). Intelectual se coloca como o único porta-voz de Auschwitz. Disponível em: www1.folha.uol.com.br/fsp/cotidian/ff13072 01130.htm.

Spinoza, B. (1990). Ética y tratado Teológico-Político. Cidade do México: Porrúa.

Traverso, E. (2004). La singularidad de Auschwitz. Un debate sobre el uso público de la historia. Nueva Época, 11(31), maio-agosto, México.

Vidal-Naquet, P. (1995). The Holocaust's Challenge to History. In L. Kritzman, (org.), Auschwitz and After: Race, Culture, and "the Jewish Question” (pp. 25-34). Nova York: Routledge. 


\section{Filmografia}

A dor e a piedade (1969), de Marcel Ophüls.

Noite e neblina (1955), de Alain Resnais.

Shoah (1985), de Claude Lanzmann. 